\title{
IAMJ
}

INTERNATIONAL

AYURVEDIC

MEDICAL JOURNAL

\section{A CASE OF CERVICAL INTRAEPITHELIAL NEOPLASIA - MANAGEMENT THROUGH AYURVEDA}

\author{
Deepthi. G. B ${ }^{1}$, Gayathri Bhat. N.V ${ }^{2}$
}

${ }^{1}$ Final Year Pg Scholar, Dept of Prasuti tantra Stree and Streeroga, Sri Dharmasthala Manjunateshwara College of Ayurveda and Hospital, Hassan, Karnataka, India

${ }^{2}$ Professor and Head of Department, Dept of Prasuti tantra Streeroga, Sri Dharmasthala Manjunatheshwara College of Ayurveda and Hospital Hassan, Karnataka, India

Corresponding Author: deepthi.gudi@gmail.com

\section{https://doi.org/10.46607/iamj3609122021}

(Published Online: December 2021)

Open Access

(C) International Ayurvedic Medical Journal, India

Article Received: 19/10//2021 - Peer Reviewed: 13/11/2021 - Accepted for Publication 08/12/2021

\section{Check for updates}

\begin{abstract}
Introduction - Cervical cancer is the $2^{\text {nd }}$ most leading prevalent cancer in India. There are an estimated 123,000 new cases of cervical cancer in India every year with 67,000 deaths in women alone. Cervical cancer in Recent studies shows that screening of cervical cancer reduces the disease incidence and disease mortality by $50 \%$. Lowgrade squamous intraepithelial lesion (LSIL) is a common abnormal result on a Pap smear cervical test. It's also known as mild dysplasia. Methodology - Here is a case report of a patient aged 26yrs with complaints of white discharge per vagina with severe itching, on routine cervical screening investigations found to have Low grade squamous intraepithelial neoplasms. She was treated with Ayurvedic sthanika chikitsa (Local therapies) such as Yoni prakshalana (Vaginal douching), and Yoni pichu (Vaginal tamponing) for 7 days along with shaman chikitsa. Later PAP smear was repeated after 1 month of follow up and found to have negative for intraepithelial neoplasia. And there was relief in the symptoms following treatment. Results- In this case, there was a relief of symptoms and on follow up when Pap smear was repeated, there was negative for intraepithelial neoplasia. Ayurvedic treatment modalities such as Sthanika chikitsa which includes yoni prakshalana and Yoni Pichu are the line of treatment for various gynecological problems and help in reducing mortality and morbidity caused due to cervical cancer in India.
\end{abstract}


Discussion- Here Low-grade squamous Intraepithelial neoplasia can be considered as the Sanchaya avastha and hence diagnosing the disease in its Sanchaya avastha i.e mild dysplasia, is important. During Sanchaya avastha there is localized neoplastic changes of cervical cells and there is Manifestation of Low-grade Intraepithelial Neoplasia. In the later stages of Kriyakala (Stages of disease manifestation) the neoplasia turns into metastasis and further differentiation occurs which Manifests all the symptoms of Cervical Cancer. Hence treatment modalities such as Yoni prakshalana and yoni pichu helps in preventing later conditions such as cervical cancer.

Keywords: Cervical Cancer, LSIL, Ayurveda, Sanchaya

\section{INTRODUCTION}

The case of a 26-year-old married, nonalcoholic, nonsmoking housewife. She complained of white discharge per vagina for 8 months. She was anxious to conceive for $7 \mathrm{yrs}$ with a history of irregular menses since $5 \mathrm{yrs}$ and is under medications. She was admitted for Basti chikitsa (medicated enema treatment) and as a part of routine investigation for cervical screening was done. She was found to have low-grade intraepithelial neoplasm hence further management was planned in the In-patient department of Prasuti tantra streeroga, SDM hospital Hassan

PRADHANA VEDANA/MAIN COMPLAINT: - Pt anxious to conceive since $7 \mathrm{yrs}$

ANUBANDHI VEDANA/ASSOCIATED COMPLAINT: -Pt c/o white discharge per vagina for 8 months.

HISTORY OF PRESENT ILLNESS: - Pt anxious to conceive since $7 \mathrm{yrs}$ with a history of irregular menses since 5yrs and is under medications. Pt was admitted for Basti chikitsa and as a part of routine investigation for cervical screening was done and pt. was found to have low-grade intraepithelial neoplasm hence further management was planned

H/O PAST ILLNESS: K/C/O PCOD since 5yrs

FAMILY HISTORY: -No history of cervical abnormal lesions in the mother and siblings

PERSONAL HISTORY/VAYYAKTIKA VRUTTANTA: -

- AHARA(Diet): -mixed

- AGNI(Digestion): - Jataragni janya

- $\operatorname{KOSTA(Bowels):-~madhyama}$

- NIDRA(Sleep): - vikruta (disturbed)

- VYASANA/ADDICTION: - nothing specific
- MALA PRAVRUTHI(Defecation): - prakrutha (Normal

- MUTRA PRAVRUTHI(Micturation): - prakrutha

- NATURE OF WORK: - Housewife

GYNECOLOGICAL HISTORY: -

- AGE OF MENARCHE: - 14 years

- LMP- 2/11/020

- MENSTRUAL HISTORY: - 2-3days /75-80days (2pads/day)

- PAIN- absent

- CLOTS- absent

- FOUL SMELL- absent

- ASSOCIATED COMPLAINTS- nothing specific OBSTETRICAL HISTORY: -Anxious to conceive GENERAL EXAMINATION: -

- $\quad$ BUILT- obese (BMI - 33.1)

- NOURISHMENT- malnourished (due to Agni mandhya)

- PALLOR- Absent

- ICTRUS- Absent

- EDEMA- Absent

- LYMPHADENOPATHY- Absent

- ClUBBING- Absent

- WEIGHT- 79.4KG, height $-155 \mathrm{cms}$

- BP- $120 / 80 \mathrm{~mm}$ of hg PR-80 bpm

DASHAVIDHA PAREKSHA: -

- Prakruthi: - Kapha pitta prakriti

- Vikriti: -Kapha pradhana tridosha

- Sara:-Meda Sara purusha

- Samhanana: - Avara

- Pramana: - Sthula deha

- Sathmya: - Sarva rasa Sathmya

- Sattva: - Madhyama

- Ahara shakti: - Madhyama 
- Vyayama shakti: - Madhyama (walking Ihr a day)

- Vaya: - Yuva

ASTA STHANA PAREEKSHA: -

- NADI: - 72 bpm

- MALA: -prakrutha

- MUTRA: - Prakrutha

- JIHWA: - Alipta

- SHABDA: - Prakrutha

- SPARSHA: - Ruksha

- DRUK: - prakrutha

- AKRUTHI: - sthula

CLINICAL EXAMINATIONS-

- P/A EXAMINATION: -soft, nonnon-tender

- P/s- Cx congestion in the upperlip, erosion+ WDPV+

- $\mathrm{P} / \mathrm{v}-\mathrm{NS} / \mathrm{AV} / \mathrm{FF}$

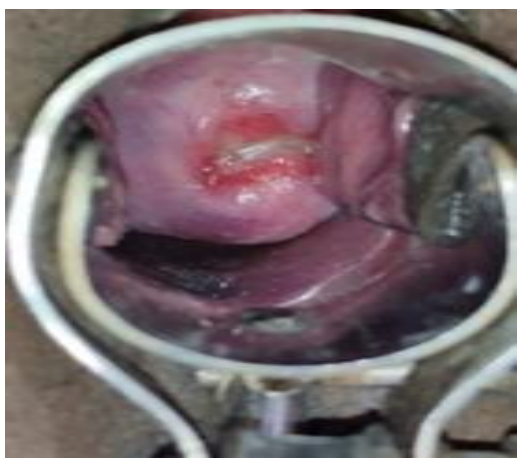

Figure 1: Per Specu-Lum Findings

ROUTINE INVESTIGATIONS - Blood and Urine routine under normal limits.

Cervical Screening-PAP Smear- Reports indicating the presence of Low-Grade Squamous intraepithelial neoplasia.

Table 1: Samprapti Ghataka

\section{Samprapthi Gataka: -}

Dosha: -

Dushya: -

Agni: -

Ama: -

Srotas: -

Srotodusti: -

Udbhava Sthana: -

Vyakta Sthana: -

Roga Marga: -

Sadyasadyata: -
Kapha, Vata

Rasa Raktaadi

Jataragni Janya

Jataragni Janya Ama

Arthavavaha Strotas

Granti, Vimarga Gamana

Garbhashaya

Yoni Mukha (Cervix)

Abhyantara

Kruchra Sadya

Table 2: Differential Diagnosis

\begin{tabular}{|l|l|l|}
\hline DISEASE & INCLUSION CRITERIA & EXCLUSION CRITERIA \\
\hline 1) Kaphaja yoni vyapat & $\begin{array}{l}\text { White discharge per vagina } \\
\text { Pain in the vagina }\end{array}$ & Pap smear reports - Mild dysplasia \\
\hline 2) Arbuda & $\begin{array}{l}\text { Purvarupa avastha of Arbuda can be included } \\
\text { Mild dysplasia on Pap smear reports }\end{array}$ & \\
\hline
\end{tabular}

FINAL DIAGNOSIS- Purva rupa avastha of Arbuda THERAPEUTICAL INTERVENTION CHIKITSA- STHANIKA CHIKITSA -

- $\quad$ Yoni abhyanga with Triphala kwatha-7days
- $\quad$ Yoni Pichu with ropana ghrita -7days

- $\quad$ Obesity diet

- Yoga and pranayama 


\section{STHANIKA CHIKITSA FOR CERVICAL NEOPLASIA}

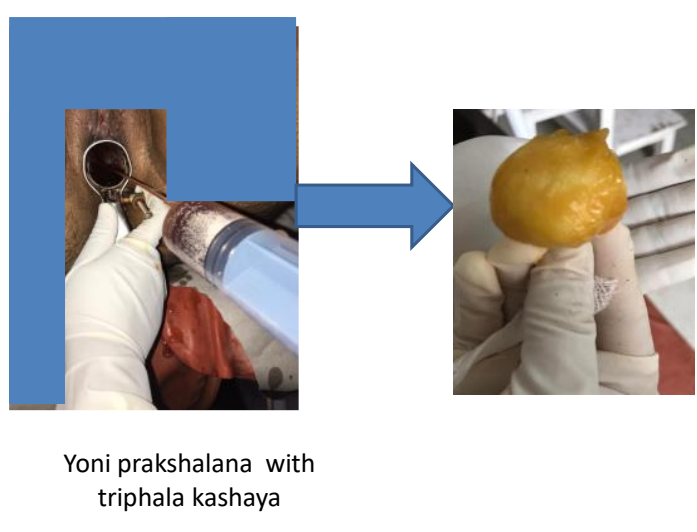

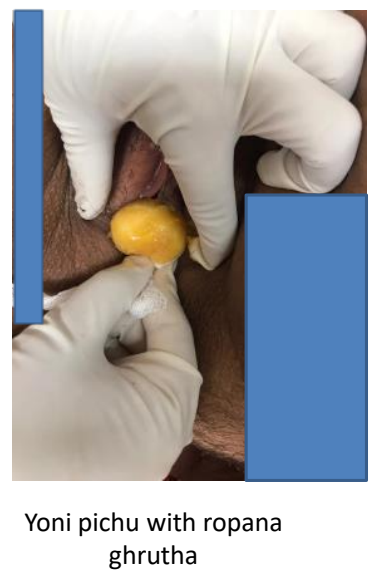

Figure 3: Demonstration of Sthanika Chikitsa (A) Yoni Prakshalana (B) Yoni Pichu

\section{RESULTS-}

Follow-ups and outcomes-

After 7 days of sthanika chikitsa, follow up was done after 1 month of the treatment Pt had relief in the symptoms, Vaginal Itching and white discharge were reduced. On repeating The PAP smear- it was negative for intraepithelial neoplasia.

According to Sushruta, When the doshas are scummed in the premonitory stage(sanchaya avastha) itself, the disease doesn't progress to further stages and the bala of the disease reduces ${ }^{3}$. Here Low grade squamous intraepithelial neoplasia can be considered as the sanchaya avastha and Hence diagnosing the disease in its Sanchaya avastha i.e mild dysplasia, is important and it helps in preventing later conditions such as cervical cancer.

\section{DISCUSSION}

DISCUSSION ON THE DISEASE - Low-grade squamous intraepithelial lesion (LSIL) is a common abnormal result on a Pap test. It's also known as mild dysplasia. It's a type of cervical cancer that is $2^{\text {nd }}$ most leading prevalent cancer in India. There are an estimated 123,000 new cases of cervical cancer in India every year with 67,000 deaths in women in India alone. ${ }^{4}$ Cervical cancer is Recent studies shows that screening of cervical cancer reduces the disease incidence and disease mortality by $50 \%{ }^{5}$. cervical Cancers can be prevented at the earliest by detecting the presence of HPV. Regular population-based Screening is done using Pap smear cytology and it is accepted as the international screening Programmed. PAP smear screening helps in detecting the pre-cancerous stages such as Low-grade intraepithelial neoplasia, Highgrade Squamous intra-epithelial neoplasia prevents Cervical Cancer. HPV (Human Papilloma Virus) is one of the most common causes of intra-epithelial neoplasms. HPV reduces the embryo's ability to implant in the uterus. HPV infections also damage the embryo and hence also one of the causes for Primary infertility in the female of reproductive age group ${ }^{6}$ 


\section{Alteration in the normal vaginal $\mathrm{pH}$}

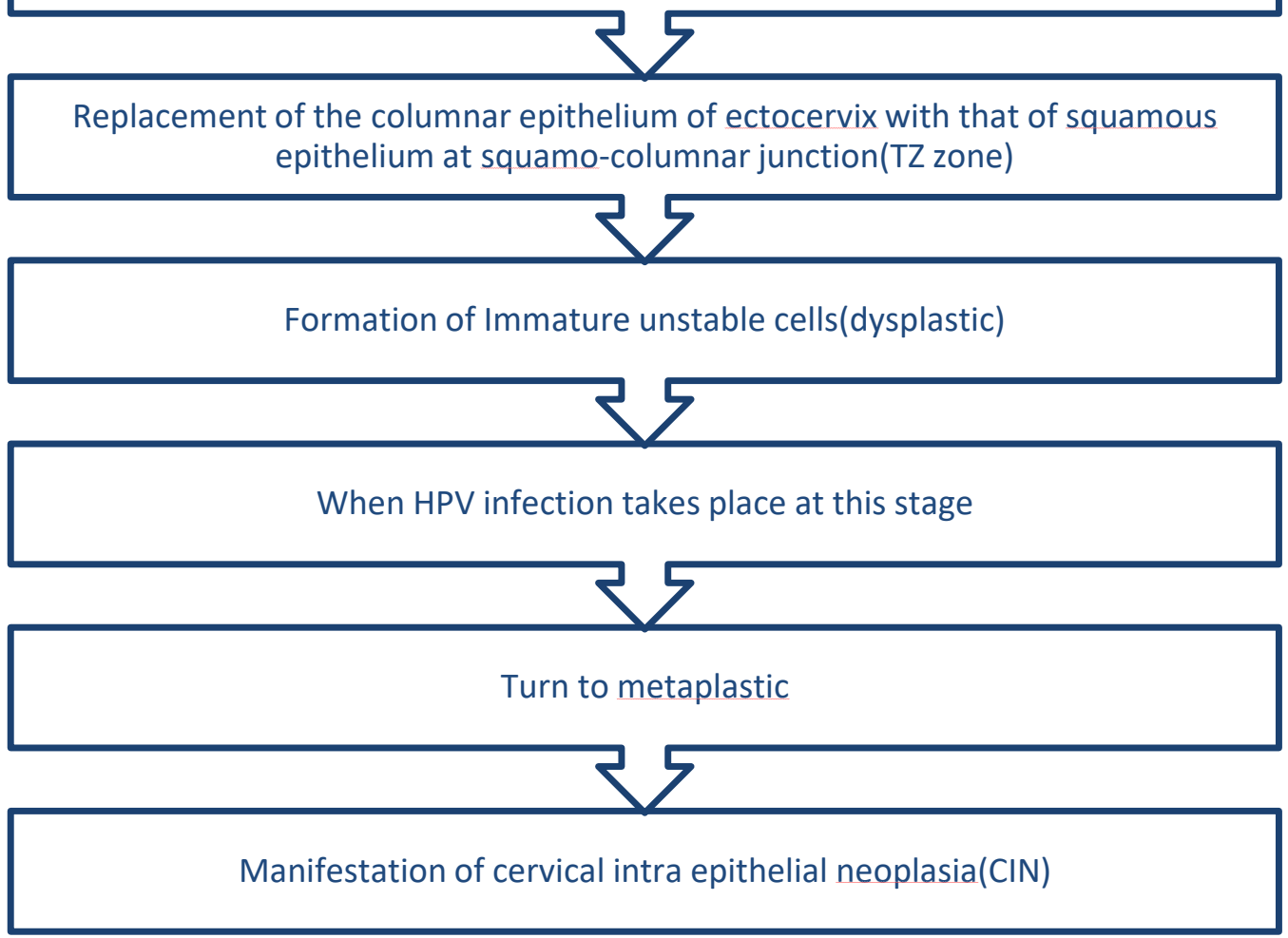

Table 3: Manifestation of CIN

AYURVEDIC UNDERSTANDING OF LSIL (LOW GRADE SQUAMOUS INTRAEPITHELIAL NEOPLASMS-

The cervical intraepithelial neoplasm can be taken as Arbuda, Granti or Dustavrana. Cancer originates due to metabolic changes. Vata dosha is responsible for cell division. Due to Dosha prakopa, there is
Aggravation of vata and Suppression of Kapha which is the major reason for the proliferation of the cells. At this stage, there is Growth of the Proliferated cells at a specific part i.e., Ekadeshabhivrudhi. Here we can consider the proliferation of abnormal cells at the cervix and further turns into Low-grade intra-epithelial neoplasm. 


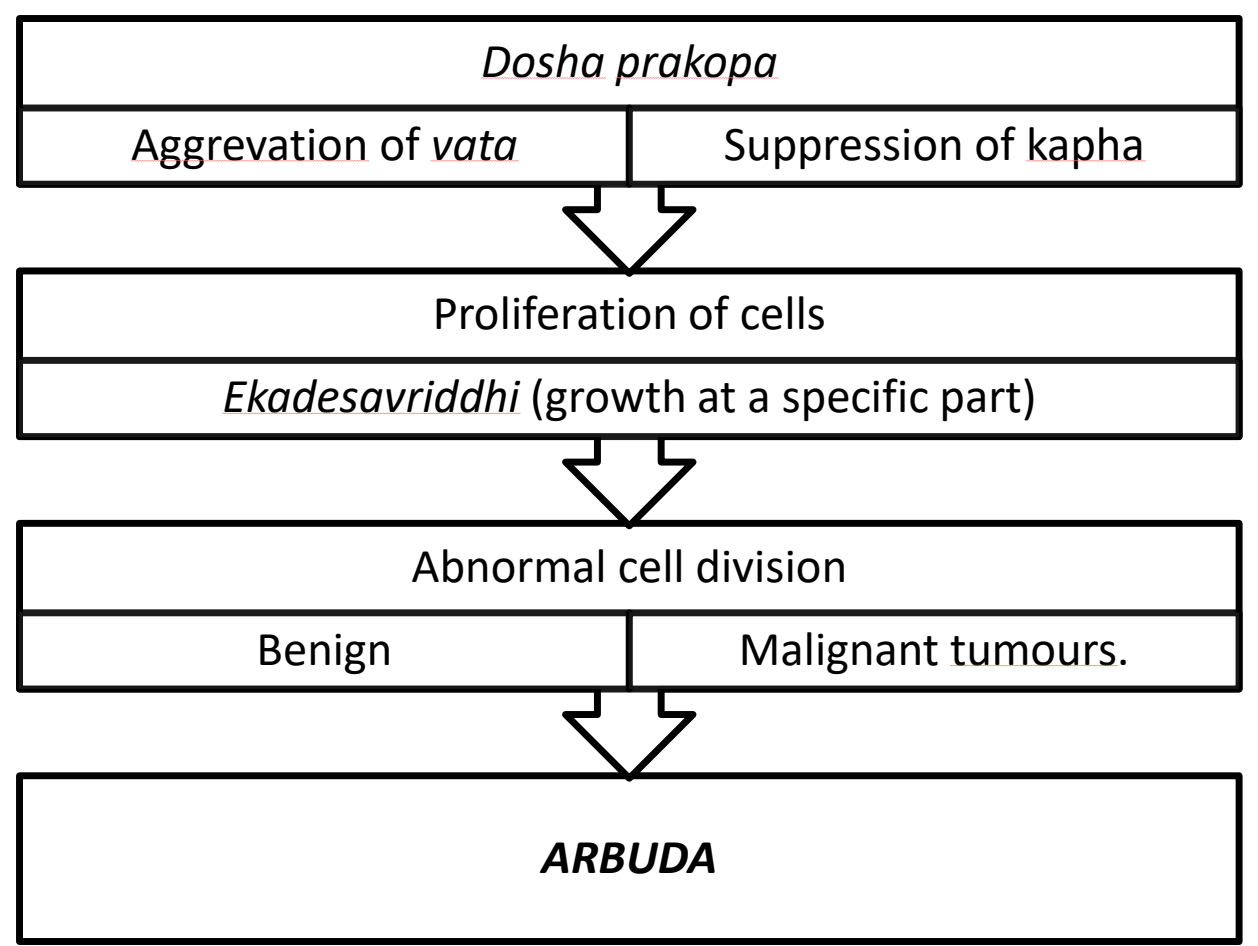

Table 4: Manifestation of Arbuda

Shad kriya Kala is disease progression acc to Ayurveda and Manifestation of Arbuda can be understood as follows-

During Sanchaya avastha there is localized neoplastic changes of cervical cells and there is Manifestation of
Low-grade Intraepithelial Neoplasia. In the later stages of kriyakala, the neoplasia turns into metastasis and further differentiation occurs which Manifests all the symptoms of Cervical Cancer.

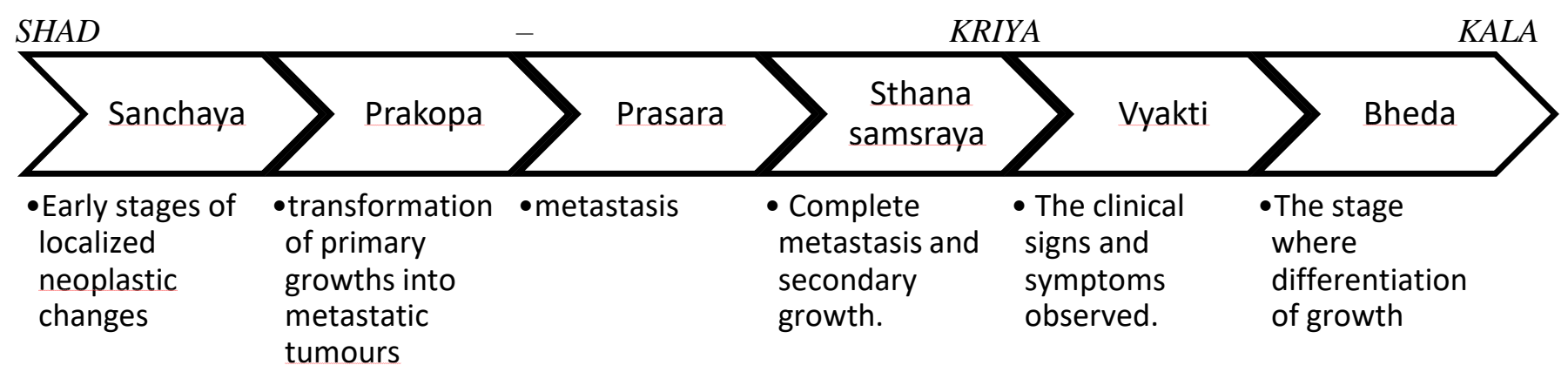

Figure 6: Shad Kriya Kala of Arbuda

\begin{abstract}
DISCUSSION ON MODE OF ACTION OF case of Yoni Srava, Yoni Paichhilyata, Yoni DaurCHIKITSA (TREATMENT GIVEN) - The treatgandhya. Triphala Kashaya is used for Yoni ment given was Yoni Prakshalana with Triphaladi Kwatha followed by Yoni Pichu with Ropana Ghrita for 7 days. Here Sthanika Chikitsa with Yoni Prakshalana. Triphaladi Kashaya is Tiktakashaya rasa pradhana, Laghu Ruksha guna and hence their action is Kaphahara, Lekhana, Kandugna, Kleda-shoPrakshalana is employed, which is indicated in the shaka, vrana shodhana and ropana, srava kleda hara,
\end{abstract}


Šthahara, vedana sthapaka. From this, it is clear that Yoni Prakshalana with Triphaladi Kwatha is Bacteriodcidal, anti-Inflammatory and it removes the debris of unhealthy tissues and dysplastic tissues. It helps in the regeneration of new tissue growth in the vaginal flora and maintains normal vaginal mucosa by maintaining the normal vaginal $\mathrm{pH}{ }^{7}$

Followed by Yoni pichu with Ropana Ghrutha was done. Ropana Ghrutha ${ }^{8}$ has the following ingredients

TABLE 5: Ingredients of Ropana Ghrutha

\begin{tabular}{|l|l|}
\hline DRUGS & PROPORTION \\
\hline Madhuka & 1 part \\
\hline Lodra & 1 part \\
\hline Sarjarasa & 1 part \\
\hline Manjista & 1 part \\
\hline Chandana & 1 part \\
\hline Moorva & 1 part \\
\hline Ghrutha & 28 parts \\
\hline Madhuchista & 1 Part \\
\hline
\end{tabular}

Ropana Ghrutha -All the ingredients are Laghu, ruksha guna pradhana and absorb the excessive moisture, smoothens the tissue; due to Tikta Madhura Rasa Pradhana, Katu Vipaka, Sheeta Veerya they are antiinflammatory, bactericidal and remove the dead cells and replaces the dysplastic tissues. By promoting the new healthy tissue formation. It acts as Pittashamaka, Shophahara, Vrana ropaka, Drusta vrana hara. Ingredients of Roopana Ghrutha demonstrates anti-cancerous, anti-tumour, anti-scavenging, cytotoxic, activity such as -

1) Londra- Acc. to niyati et all Symplocos racemose bark showed potent antioxidant and anticancer activity. It may be due to the presence of phytochemicals that are responsible for the anticancer activity. ${ }^{9}$

2) Madhuka - Acc to asima et all. The in vitro cytotoxicity was performed against five human cancer cell lines namely of the lung (A-549), liver (Hep-2) colon (502713 HT-29) and neuroblastoma (IMR-32). Against lung (A-549) cell line plant extract showed $83 \%$ growth of inhibition. plant extracts showed selective in vitro cytotoxicity, active against some human cancer cell lines and others, not show activity.

3) Manjista - Methanol fraction of Rubia cordifolia extract exhibited potent inhibition of Human cervical cancer cell line and Human larynx carcinoma cell line while was found to be less cytotoxic against normal human kidney cells displaying safety for normal cells. 10

4) Chandana- Enhanced GST activity and acidsoluble SH levels were suggestive of possible chemopreventive action of sandalwood oil on carcinogenesis through a blocking mechanism. topical application of $\alpha$-santalol demonstrated chemopreventive effects as observed from reduced ornithine decarboxylase activity, tumour incidence, and multiplicity ${ }^{11,12}$

Yoni Pichu helps in penetration of these drugs into the tissue and helps in absorption of these drugs due to its Sukshma, Vyavaayi guna and lipophilic property, thus helping in nourishing the pelvic tissues. here Yoni Pichu is removed into amutra Kala (until the next urge of micturition). Hence these drugs retain in the vagina for a longer period and help in better action. It helps in normalizing the Apana Vata and maintains a healthy vaginal symbiosis.

These two treatment modalities which are the vaginal therapies act through the vaginal drug delivery system. The vaginal epithelium is made up of 40 distinct layers and the range of the epithelium creates an involuted surface that covers a large surface area, approximately $360 \mathrm{cms}$. And the vaginal administration of drug delivery surpasses the first-pass metabolism and ease the administration of the drugs and have high permeability for low molecular weight drugs which are lipophilic such as ghrutha. Hence the trans-epithelial absorption 
via the vaginal route helps in easy and quick absorption of the medications.

Overall Sthanika Chikitsa (Treatment modalities which include Yoni Prakshalana and Yoni Pichu) helps in -

- Imparts dryness and denatures the microorganisms (HPV)

- Helps in the maintenance of the $\mathrm{pH}$ and by regaining normal vaginal $\mathrm{pH}$,

- Healthy layer on the cervix

- Regeneration of healthy cervical epithelia

- Healing of CIN - 1 lesion (LSIL)

\section{CONCLUSION}

LSIL (Low grade squamous intraepithelial lesions) can be considered as the Purvarupa avastha of Arbuda which left untreated will cause cervical cancer. Doshasya apahruta dosha Labate a Uttara Gati hence during its Sanchaya avastha only if proper treatment is given, it doesn't progress to other Kriyakala stages. Hence Integrative management of precancerous stages should be adopted.

\section{REFERENCES}

1. Kashinath Pandey And Gorakhnath Chaturvedi Charak samhita Vidyotini vyakhya Part -I chikitsa Sthan 1314/30 Reprint 2009 Varanasi Chaukambha Bharti Academy

2. Shastri A D. Susruta Samhita (Purvardha) with Ayurveda-Tatva-Sandipika Hindi commentary. Reprint ed. Varanasi: Chaukhambha Sanskrita Sansthan; 2005. nidanasthana, sloka No. 13

3. Shastri A D. Susruta Samhita (Purvardha) with Ayurveda-Tatva-Sandipika Hindi commentary. Reprint ed. Varanasi: Chaukhambha Sanskrita Sansthan; 2005. Sutrasthana, sloka No. 21/39

4. Senapati R, Nayak B, Kar SK, Dwivedi B. HPV Genotypes distribution in Indian women with and without cervical carcinoma: Implication for HPV vaccination program in Odisha, Eastern India. BMC infectious diseases. 2017 Dec;17(1):1-0.

5. Franco EL, Duarte-Franco E, Ferenczy A. Cervical cancer: epidemiology, prevention and the role of human papillomavirus infection. Cmaj. 2001 Apr 3;164(7):1017-25.
6. https://screening.iarc.fr/doc/WHO_India_CCSP_guidelines_2005.pdf

7. Priyanka Teva, Kalpna Sharma, Hem Prakash. Mode of Action of Sthanik Chikitsa in Commonly Used in Stree Roga. AYUSHDHARA, 2020;7(Suppl 1):36-41.

8. Sharanghadhara, Sharanghadhara Samhita English translation By Prof. K.R. Srikanthmurthy Chaukhambha Orientalia Varanasi, Second edition 1995 madyama khanda 9/1-2

9. Niyati A, Unnati S, Lal H, Sanjeev A. Antioxidant andanti-cancer potential of Symplocos racemosa bark against Hep3B cell line. International Journal of Pharmaceutical Sciences and Research (IJPSR). 2015;6(10):4529-33.2)

10. Patel PR, Nagar AA, Patel RC, Rathod DK, Patel VR. In-vitro anticancer activity of Rubia cordifolia against Hela and Hep-2 cell lines. Phytomedicine. 2010; 2:446.

11. Dwivedi C, Valluri HB, Guan X, Agarwal R, Chemopreventive effects of $\alpha$-santalol on ultraviolet $B$ radiation-induced skin tumour development in SKH-1 hairless mice. Carcinogenesis, 2006; 27: 1917-1922

12. Kumar R, Anjum N, Tripathi YC. Phytochemistry and pharmacology of Santalum album L.: A review. World Journal of Pharmaceutical Research. 2015 Aug $4 ; 4(10): 1842-76$.

\section{Source of Support: Nil \\ Conflict of Interest: None Declared}

How to cite this URL: Deepthi. G. B \& Gayathri Bhat. N.V: A Case Of Cervical Intraepithelial Neoplasia- Management Through Ayurveda. International Ayurvedic Medical Journal \{online\} 2021 \{cited December 2021\} Available from: http://www.iamj.in/posts/images/upload/3143 3150.pdf 